\title{
Development of a Costs Simulator to Assess New Maritime Trade Routes
}

\author{
F.X. Martínez de Osés, M. Castells i Sanabra \& M. Rodríguez Nuevo \\ Nautical Science and Engineering Department, Universitat Politecnica de Catalunya, \\ Barcelona, Spain
}

\begin{abstract}
This paper is going to describe the design process of a simulator that assesses the costs of different means of transport. The evaluation not only will be done regarding the internal costs but also the external costs that will be translated to environmental costs, based on existing databases. The paper shows the development carried out to create this simulator and analyse all components of the logistical chain, i.e. port operation costs, road haulage costs and maritime leg costs. The simulation results have been validated with real data of actual maritime routes to check its reliability. As a conclusion, the costs simulator permits assess costs of new maritime trade routes comparing them with road transport.
\end{abstract}

\section{INTRODUCTION}

One of the main challenges identified by the European Commission White Paper on transport was to address the imbalance in the development of the different modes of transport. Specific actions looking to boost rail and maritime connections were foreseen and included the establishment of the Marco Polo programs. The demand for increased mobility and increased flexibility and timeliness of delivery has led to road transport becoming the dominant mode of transport in the European Union. The growth in road transport has had a significant impact on road congestion, road safety, pollution and land use. In view of this, a change from traditional unimodal to multimodal transport is desirable. Maritime transport is one of the least pollutant modes. Additionally, it contributes to the reduction of traffic congestion, accidents and noise costs on European roadways. Another advantage of ships over trucks and trains is that vessels consume less fuel as a result of the relatively low speeds at which they travel. All these advantages justify support actions to intermodal chains with marine sections including Short Sea Shipping (SSS) as a way to reach more sustainable mobility within Europe. The main benefit of Short Sea Shipping lies in the possibility of combining the inherent advantages provided by the involved modes, thus reducing costs and increasing freight transport capacity over long distances.

Nevertheless, maritime society still regards maritime transport as a slow, inefficient mode since shippers do not yet offer the best value for money.
This paper shows the development carried out to create a simulator that compares freight transport by only road chains and by multimodal (with SSS) chains and comprises five sections. The introductory section summarises the context of the paper. Section two describes the actual scenario related on the state of art of freight costs simulators. A brief description of the methodology used in the development of the costs simulator is explained in section three. The results obtained using costs simulator tool are shown in the next section. Finally conclusions and further research are drawn in section five.

\section{FREIGHT COSTS STATE OF ART}

The determination of cost functions and variables is important in assessing the feasibility of a process. Historically, the empirical estimation of port cost functions started in the 60's with Wanhill's work. The works by De Monie, Dowd and Lechines, Talley and Conforti proposed a cost analysis to appraise port performance and output by calculations of several indicators. Ametller Malfaz thesis describes the development of cost and time evaluation under the hypothesis of freight distribution based on population density. Actual cost and time simulators an be divided into two groups: the first one a few parameters must be introduced to determine cost or time without specifying the method used; the second one calculates external costs based on theoretical studies like Realise and Recordit projects. 


\section{DEVELOPMENT OF THE COST SIMULATOR}

This paper presents a simulator of internal and external costs which also allows updating data. In order to design the simulation model, the behavior of freight distribution systems must be known. Road haulage, port operation and maritime leg must be modeled to assign costs derived from each of the parts or components of the logistic chain.

The calculation method of overall costs (in $€$ ) have been calculated considering a single variable (Gross Tonnage) for all transport modes.

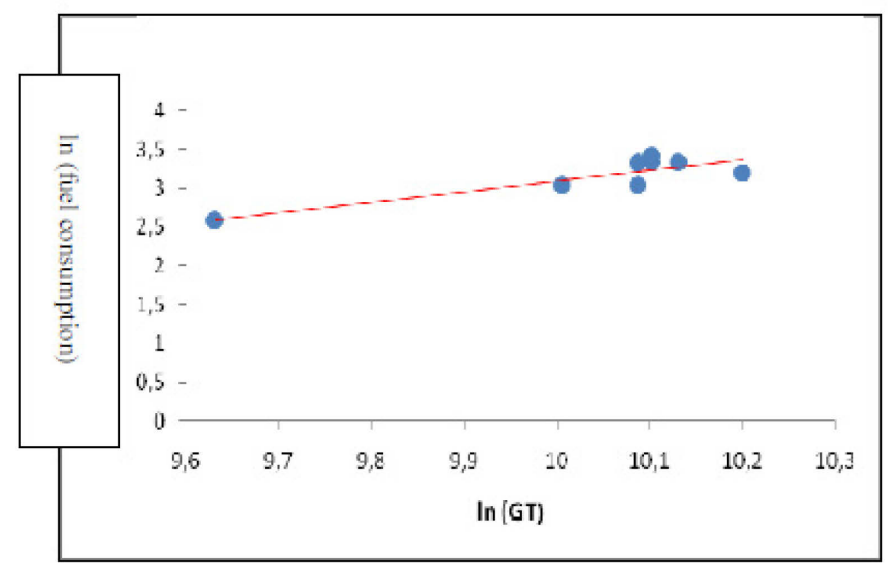

Figure 1.Example of logarithmical ratio between fuel costs and gross tonnage (GT). Source: Own

Time (in hours) spent by the modes of transport to move freight between an origin and a destination will strongly depend upon the physical and operation speed of the modes employed. Calculations consider European road transport regulations on driving times and costs of road freight transport.

Data of truck internal costs will be obtained by analyzing a set of model trucks specified by the Ministry of Public Works and for vessels, Short Sea Shipping Ro-Ro ships are ships employed in Mediterranean maritime routes.

All required data is computed by an engine generated by an Excel spreadsheet and a computer program complied in Visual Basic, and then presented in tables and graphs.

After we have introduced all required data, the methodology used by de simulator can be summarized by the following steps:

1 Choose data from the destination matrix and find out whether there is a destination for the selected route.

2 Choose data from the origin matrix and find out whether there is an origin for the selected route.

3 Choose data from the maritime distance matrix.

4 Introduce ship occupancy rate $(\sigma)$.

5 Introduce type of freight $(\sigma)$.
6 Introduce the number of stops made by the ship in each trip $(\rho)$.

7 Introduce specific company profits as a payment for ship services $(\beta)$.

8 Print and display all solutions for the selected ship (calculation of Short Sea Shipping and only road transport costs and pollutant emission costs).

9 Choose the three best ships for the selected route from the simulator's database and provide their particulars (ship's name, year of building, length, breath, tonnage, lane meters, power, speed and number of platforms).

10 Perform routines under the established formulation.

All data are interpreted by means of tables, charts and mask designed for the presentation of simulator data.

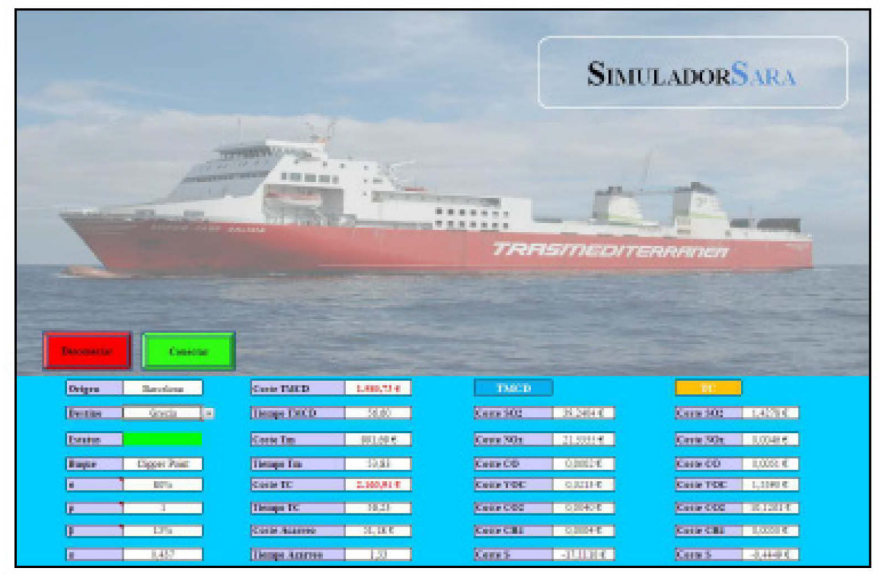

Figure 2. Example of the mask showing parameters to be selected before the calculation process and results of external and internal costs. Source: Own

\section{PRELIMINARY RESULTS EXAMPLE FROM THE COSTS SIMULATOR}

Once we have designed the costs simulator, we have analyzed routes between Spain and the Black Sea region, considering the imminent entrance of candidate East and Middle European countries into the European Union. Trade operations with all these countries open the door to two big markets: Central Asia and the Middle East. The number of volumes exchanged between Spain and the Black Sea Region shows and upward trend. The total volume of exports and imports between Spain and the Black Sea region is approximately 3,941,806.1 and $24,898,406.1$ tons, respectively, value that justifies the management of a trade route between both regions. The data were obtained from figures regarding Spanish import and export operations with Bulgaria, Georgia, Romania, Russia, Turkey and Ukraine, although the countries with the highest number of exchanges with Spain are Greece, Turkey, Russia and Ukraine. 
Costs ant times differences for all possible routes between Spain and the Black Sea region have been calculated considering multimodal and road transport. Next tables show the results between different Spanish origins and Black Sea Area.
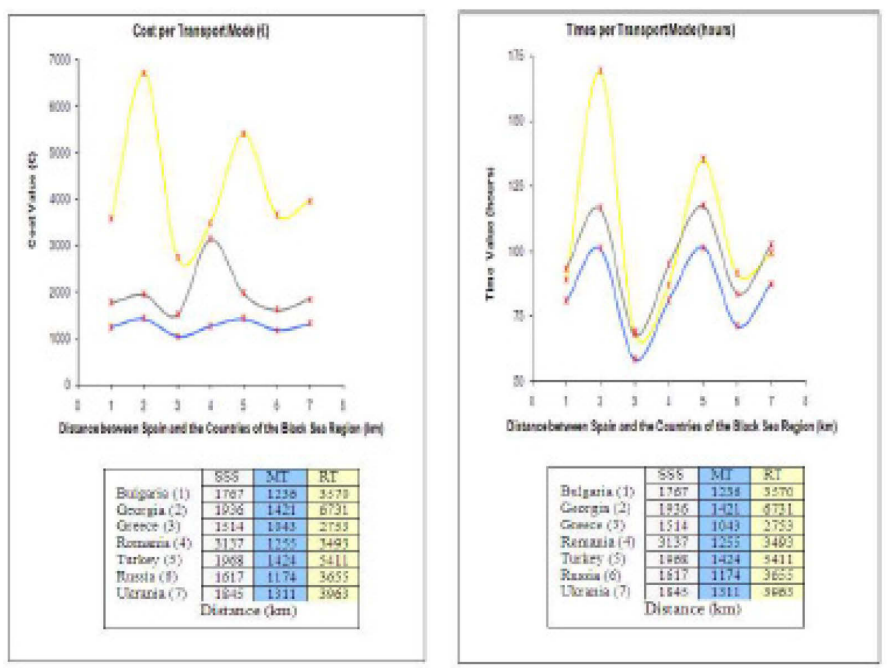

Figure 3: Costs and times differences between multimodal and road transport from Spain to Black Sea region. Source: Own

After the most important exchanges have been selected, Cost Competitiveness Index (CCI) and Time Competitiveness Index (TCI) are calculated. If the resulting value is more than one, then the Short Sea Shipping alternative is more competitive in costs and in time than the only road alternative.

Table 1: Example of Cost Competitiveness Index (CCI) and Time Competitiveness Index (TCI) between Spain and Turkey (Istanbul port). Source: own

\begin{tabular}{llcc}
\hline & TCI & CCIa & CCIb \\
\hline Barcelona & 1,828896 & 2,2809114 & 3,946985 \\
Cádiz & 1,643525 & 1,9559147 & 2,704304 \\
Madrid & 1,746747 & 2,1564750 & 3,306404 \\
Murcia & 1,848956 & 2,3061440 & 3,675953 \\
Valencia & 1,937316 & 2,4842342 & 4,365663 \\
Vizcaya & 1,491680 & 1,7688517 & 2,509041 \\
Zaragoza & 1,70757 & 2,0653322 & 3,175024 \\
\hline
\end{tabular}

Next figure shows the results of Cost Competitiveness Index of SSS versus only road transport between Spain and the Black Sea region routes:

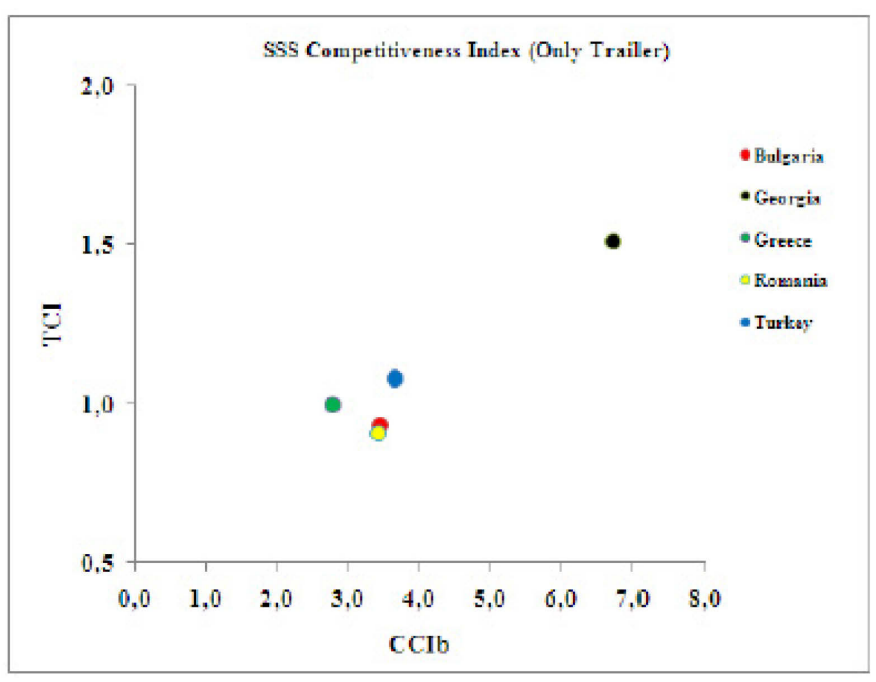

Figure 4: Cost Competitiveness Index of SSS versus only road transport between Barcelona and the Black Sea. Source: Own

From results obtained, we can state:

- The Time Competitiveness Index (TCI) determined that SSS routes between Spain and Georgia and Spain and Ukraine are the most efficient in terms of time.

- The Cost Competitiveness Index (CCIa) determined that SSS routes with the driver, truck and trailer onboard the ship are more competitive in terms of cost than the above case.

- The Cost Competitiveness Index $(\mathrm{CCb})$ determined that SSS routes with only the trailer onboard the ship are the most competitive in terms of cost.

\section{CONCLUSIONS AND FURTHER RESEARCH}

A design process of a simulator for the assessment of internal and external costs of an only road chain and an intermodal one has been designed. Costs simulator is a fast tool to help customers decide on the most convenient transportation mode for a specific trade link.

This model has been validated according to data from actual commercial exchanges. This validation analysis is quite successful and the simulator data are very close to real prices. The difference between the model data and real data do not exceed $10 \%$.

In this paper we have studied the special case between Spain and the Black Sea Region but the tool presented can assess new maritime trade route comparing with road transport.

A more in deep analysis should be carried out. Data obtained can be used for further research, affording prediction of emissions in the near future by keeping in mind the traffic and fleet evolution and the existing legislation and can also be used to check price variations due to commercial reasons. 


\section{REFERENCES}

Ametller Malfaz, X. 2007. Optimización del transporte de mercancías mediante el TMCD. UPC Thesis.

Conforti, M. 1992. Productivity scrutinized. 7th Terminal Operations Conference. Cristoforo Colombo Congreso Center. Italy.

De Monie, G. 1989. Medición y evaluación del rendimiento y de la productividad de los puertos. Monographies of the UNCTAD on Port Management, no 6. New York.

Directive 2002 CE, of 18th February 2002,

Dowd, T.J. and Leschine, T.M. 1990. Container terminal productivity: a perspective. Maritime Policy and Management. Vol. 17, no 2, pp.107-112.

European Commission. 2001. The White Paper on Transport: towards 2010. Time to decide. Brussels. http://ec.europa.eu/transport/strategies/2001 white_paper_en.htm

European Commission. 2002/15/EC Directive of the European Parliament and of the council of 22 March on the organization of the working times of persons performing mobile activities.

European Commission. Sustainable future for transport: Towards to integrated technology-led and user, COM (2009) 279/4 DGTREN.

Floedstroem, E. 1997. Energy and emission factors for ships in operation. KFB Rep. Swedish Transport and Commerce Res. Board. Swedish Maritime Administration and Mariterm AB. Gothenburg. Sweden.

García Menéndez, et al. 2004. Determinants of mode choice between road and shipping for freight transport. Journal of transport economics and pol- icy. Vol. 38, Part 3.
Martínez de Osés, F.X. and Castells M. 2009. Sustainability of Motorways of the Sea and Fast Ships.

Martínez de Osés, F.X and Castells, M. 2009. Análisis de la aplicación del ecobono en los tráficos marítimos espanoles. Barcelona digital, S.L.

Mulligan, R. Et al. 2006. Short Sea Shipping. Alleviating the environmental impact of economic growth. WMU Journal of Maritime Affaires. Vol. 5, Part 2: 181-194.

Realise Project. Regional Action for Logistical Integration of Shipping across Europe. 2005. AMRIE. 5th Framework Program of the European Union. [http://www.realisesss.org].

Recordit Project. Real Cost Reduction of door-to- door intermodal Transport. 2001. Supported by the Commission of the European Communities. DGVII. R\&DProject, Integrated Transport chains. [www.recordit.org]

Rodríguez Nuevo M et al. 2010. Proposal of a costs simulator, for traffics between Spain and the Black Sea. 3rd International Conference on Maritime and Naval Science and Engineering. Romania

Spanish Ministry of Transport. 2010. Observatorio de costes del transporte por carretera. Secretary of transport, pp. 3233.

Talley, W.K. 1994. Performance indicators and port performance evaluation. Logistics and Transportation Review, Vol. 30, no4, pp. 339-352.

TERM. Transport and Environment Reporting Mechanism. European Environment Agency. 2002.

Wanhill, Stephen Robert Charles. 1974. Optimum size seaport - a further analysis 